\title{
Cry me a river: metaphoric hyperboles in the interface between discourse and cognition
}

Solange Coelho Vereza

\begin{abstract}
This paper aims at analyzing metaphor as a frequent semantic realization of "the language of excess" (WEBB, 1993), i.e., hyperbole. The hypothesis to be explored is twofold: firstly, from a discursive perspective, hyperbole aims at transcending a language repertoire available for expressing intensity and gradability, and as a corollary of that, subjectivity and evaluation. In this respect, metaphor, both conventional and novel, realizes, linguistically, this intensity with both discursive and cognitive effects, by drawing elements of the source domain which serve this dual purpose. The second hypothesis to guide our research refers to the conceptual nature of the vehicle term, in other words, the metaphoric hyperbole used. Our suggestion is that, within a conceptual scale involving elements of a particular frame, the one which is selected is the prototype of that category, which is used metaphorically with hyperbolic effects. The theoretical framework underlying the research involves the concepts of hyperbole, as defined by Claridge (2011), graduation (MARTIN; WHITE, 2005), conceptual metaphor (LAKOFF; JONHSON, 1980) and prototype (ROSCH, 1979, 1983). A brief analysis of the conventional hyperbolic expression cry me a river, with examples drawn form a general corpus, will illustrate the discussion presented in the paper.
\end{abstract}

Keywords: hyperbole; metaphor; cognition.

a Professora Titular da Universidade Federal Fluminense, svereza@uol.com.br. 


\section{Introduction}

In the children's book Hyperbole: extensive exaggerations to make a point (2010), the author, Claire Gibean, provides several examples of what, in her view, would be instances of hyperboles in English. From the thirty-two hyperbolic sentences presented in the book - each occupying, with an accompanying picture, a single page -, ten are listed as follows:

(1) You are eating like pigs.

(2) The bold colors in the painting made his eyes pop out of his head.

(3) Re ran faster than the speed of lightning.

(4) Theses bags weigh a ton.

(5) This teacher is as old as Methuselah.

(6) I'm so tired, I could sleep for twenty years.

(7) His anger was so uncontrollable, it grew like the eruption of mountain Vesuvius.

(8) He hit the ball so hard it travelled a mile out of the stadium.

(9) Daughter, if you go back to that boyfriend, it will be like jumping from the fry pan into the fire.

(10) When her boyfriend broke off their engagement, she cried a river.

Some preliminary considerations can be made about these examples. Firstly, most of them contain highly conventionalized expressions in English, whose definitions can be found in electronic dictionaries:

1 Available at: $<$ ht $\mathrm{t}$ :// idiom s. thefreedictionary.com>. Access: Sept. 2014.

${ }^{2}$ Available at: <http:// dictionary.cambridge. org/pt/dicionario/ britanico $>$. Access: Sept. 2014.

${ }^{3}$ Available at: <http:// dictionary.cambridge. org/pt/dicionario/ britanico $>$. Access: Sept 2014.
- "Jumping from the frying pan into the fire is an idiom with the general meaning of escaping a bad situation for a worse situation". ${ }^{1}$

- "as old as Methuselah is used to say that someone is very old". $^{2}$

- "eyes pop out of your head is a way of describing the way you look when you are extremely surprised to see something or someone" ${ }^{\prime \prime 3}$. 
- "greased lightning is something incredibly fast (now mainly used in comparison: like or faster than greased lightning)" ${ }^{\prime \prime}$.

- "eat like a pig (informal) is to eat a lot, or to eat noisily and unpleasantly"5.

- "cry someone a river is to weep profusely or excessively in the presence of another person" ${ }^{\prime \prime}$.

It is interesting to note that all these definitions (except for the first one in the list) include an adverb of degree ${ }^{7}$ : very old; extremely surprised; incredibly fast; eat a lot; weep profusely or excessively. This seems to give further linguistic evidence of the commonsensical view concerning the intensifying function of hyperboles.

Secondly, the hyperbole in (7), thoughless conventionalized (it could not be found in a Google Search), is not likely to cause major difficulties in understanding, provided there is shared knowledge concerning the famous devastating eruption of the Italian volcano.

Thirdly, and most importantly for the purpose of the present paper, a distinction can be identified between a): those hyperboles whose exaggerating effect is achieved through the extension of a particular and somehow measurable quantity unit (referring to length, weight, size etc.), and b): those which promote exaggeration through non-quantifiable terms. The examples belonging to the first category (a) are:

${ }^{4}$ Available at: <http:// en.wiktionary.org> Access: Sept. 2014.

5 Available at: $<$ ht $\mathrm{p}: / /$ id io m s. thefreedictionary.com>. Access: Sept. 2014.

${ }^{6}$ Available at: <http:// en.wiktionary.org. Access>: Sept. 2014.

7 Following Klein (1998), we use the term "adverb of degree", and not intensifier, for instance, since "it is the neutral term, covering all degree modifying adverbs" (p. 23).
(4) These bags weigh a ton.

(6) [...] I could sleep for twenty years.

(8) [...] it travelled a mile out of the stadium.

The exaggeration in these examples implies the extension of a particular measure unit to an extreme point in the gradability or degree scale that would normally be considered unrealistic (i.e., exaggerated), in a particular context. The communicative intend underlying this kind of hyperbole seems to be to stress what is perceived, by the speaker, as a degree far above (or below) the expected average. In these three examples, respectively, the weight of the bags are extended 
probably from around 50 kilos to a ton, from perhaps 12 hours of sleep to 20 years and, finally, from approximately 100 yards to a mile. In other words, the hyperbole, motivated by the speaker's subjective evaluation of the intensity or strength of a particular phenomenon, moves along some scale of gradability, from an expected to an extreme point in this scale.

In examples (1), (3), (5), (7), (9) and (10), on the other hand, the hyperbolic expressions do not merely indicate a further and/or extreme point on a particular scale. They seem to convey an exaggerated claim about a particular state of affairs through the reference to another semantic domain: a person who eats a lot is a pig; if someone is very surprised, their eyes pop out of their heads; a fast runner is like a lightning; if you cry a lot, you cry a river and so on.

In other words, the hyperbolic expressions, in these cases, rely on mappings from one semantic domain to another. Such cases of hyperboles, thus, seem to be, from a cognitive perspective, metaphorically motivated. Or, it might even be argued, these expressions would be cases of metaphors used with hyperbolic effects.

Within this perspective, the overall aim of this paper is to discuss the ways metaphors and hyperboles may interact in language and in thought. In particular, it is our intention to explore the following questions: a) What are the conceptual implications of distinguishing hyperbolic metaphors from metaphoric hyperboles? Why opting, theoretically, for the latter?; b) How can insights from Cognitive Linguistics contribute to the understanding of metaphoric hyperboles?, and c) In what way can the study of metaphoric hyperboles in real language use shed light on the interface between Pragmatics and Cognition?

To explore these issues, the paper draws, mostly, on theoretical insights into hyperbole proposed by Webb (1993) and Claridge (2011), and into the concept of graduation, as a category of the Appraisal System, proposed by Martin and White (2005). We will also present the results of an analysis of a single metaphoric hyperbole in English, included in the list above: Cry me a river. This brief analysis, deductively in nature, will be used mainly to illustrate some considerations that will be made throughout the paper. 


\section{Why studying hyperbole?}

According to the Cambridge University Dictionary, a hyperbole is "a way of speaking or writing that makes someone or something sound bigger, better, more, etc. than they are ${ }^{\prime \prime 8}$. Following this definition, in the same Web Dictionary, in the "grammar section", a description of the function and use of hyperboles is offered: We use hyperbole to exaggerate. We sometimes do this to emphasise something, to add humour or to gain attention. When we use hyperbole, we often make statements which are obviously untrue.

The real-life examples provided by the same dictionary are all of category (a) mentioned above, i.e., they refer to an exaggerated unit of measure (amount, size, degree etc):

(11) I have lived in Nottingham since I came here to study at the university. Been here for about a thousand years.

(12) I've got tons of homework to do.

(13) You have to wait for hours in that bank.

(14) Every car in America is ten times the size of ones in Europe.

(15) There were millions of people in Woolworth's.

The notion that hyperbole, then, is a way of speaking used with the purpose of exaggerating, and that to exaggerate, according to the same dictionary, is "to make something seem larger, better, or worse than it really is", which is almost the same definition given to hyperbole, quoted above, makes exaggeration at least a near synonym to hyperbole. A very subtle difference between the two terms would probably be that the former refers, in most cases, to the communicative effect and the latter to the linguistic expression used to determine such effect. In other words, we use hyperbole to exaggerate, and we exaggerate to "emphasize something, to

${ }^{8}$ Available at: <http:// dictionary.cambridge. org/pt/gramatica/ gramatica-britanica/ hyperbole>. Access: Sept. 2014.

${ }^{9}$ Available at: <http:// english.tutorvista. com/literary-response/ hy perbole.htm l> Access: Nov. 2014. add humour or to gain attention"

It is part of common sense that exaggeration is somehow a deviation, in terms of degree, of what could be considered the true (or real) condition of what it refers to. A person who is exaggerating is not telling the truth; however, they are not necessarily engaged in a canonical act of lying, because, in most cases, what is exaggerated is not intended to be hidden; rather, 
10 Besides the grammatical suffix "issimo(a)", other grammatical superlative constructions in Portuguese have been studied. Among these, the metaphorically motivated superlative negative construction in Portuguese (SNCP), as in "não mover uma palha", "não dar um passo" "não avançou um milímitro", should be highlighted. This construction has been identified and analyzed by Miranda (2009), who argues in favor of an approach that rejects a dichotomy between the semantic and the pragmatic levels of meaning, grammar and lexis, internality and externality and language and cognition. ${ }^{11}$ José Dias amava os superlativos. Era um modo de dar feição monumental às ideias; não as havendo, servia a prolongar as frases.

${ }^{12}$ De todas as palavras de José Dias uma só me ficasse no coração; foi aquele gravíssimo. Vi depois que ele só queria dizer grave, mas o uso do superlativo faz a boca longa, e, por amor do período, José Dias fez crescer a minha tristeza. [...] nada há mais feio que dar pernas longuíssimas a ideias brevíssimas. it is a distortion of degree to the effect of accentuating the intensity of something that has somehow struck the speaker as stronger than expected.

Even though it is not necessarily considered an act of lying, exaggeration is often seen from a negative perspective; it is certainly not a virtue. In Portuguese, one way of exaggerating is by using one of the suffixes íssimo(a), -imo(a) ou érrimo(a $)^{10}$ which intensify the adjective they accompany, so that something/someone very beautiful (lindo/a) could be referred to as lindissimo/a. Used, however excessively, the suffix could convey the effect of exaggeration, impairing the veracity of the claim over the intensity of something. The well-known $19^{\text {th }}$ century Brazilian writer, Machado de Assis, in Dom Casmurro, created a character, José Dias, who "loved the superlatives", employing them excessively in his everyday interactions. The narrator expresses his view on this habit:

It was a way to provide monumental features to his ideas; as there are none, it served to extend the sentences ${ }^{11}$. From all the words Jose Dias used, only one remained in my heart: gravissimo (very serious). I realized later that he only meant grave (serious), but the use of superlatives makes the mouth bigger, and for the sake of love for the sentence, Jose Dias made my sorrow increase. [...] there is nothing uglier than giving extremely long legs to extremely brief ideas ${ }^{12}$.

The superlatives, therefore, can be seen as one of the many linguistic materializations of exaggeration. Hyperbole seems to share the same commonsensical negative connotation, and it is, therefore, seen with a certain degree of suspicion.

Among the traditional figures of speech, hyperbole has been somewhat neglected by theoreticians, who have devoted a lot of attention to studying metaphor, particularly since the advent of the so-called Cognitive Paradigm, formally introduced by Lakoff and Johnson (1980), and, more recently, to metonymy (DIRVEN; PÖRINGS, 2003; BARCELONA, 2003). In this respect, Claridge (2013, p. xiii) has pointed out that "hyperbole is still a largely under-researched field, in particular in contrast to the wealth of material available on other figures of speech, such as metaphor and irony".

Is his book, Blessed Excess, Webb (1993) has elaborated, from a critical perspective, on this neglect to hyperbole: 
Hyperbole is the poor relation of the tropes family, treated like a distant relative whose family ties are questionable at best. It is an illegitimate trope, rarely analyzed like or the equally popular trope of irony. After all, Aristotle argued that the effective use of metaphor is a sign of genius, but it is assumed that anyone can hyperbolize. Moreover, hyperbole is morally suspect because it is thought to be a sly and yet easily discernible attempt to say more than what the situation allows. It is also associated with fanaticism and insincere flattery. (WEBB,1993, p. 4-5)

Another possible explanation for the way hyperbole has been overlooked in the recent literature involving figurative language, particularly within a cognitive perspective, is the fact that it has been approached more in terms of its pragmatic effect than its semantic dimension. Stern (2000) categorizes hyperbole, together with irony, meiosis, understatement and overstatement, as a "(I)-type figure". The (I)-type figures stand in contrast to the "(M)-type" ones: metaphor, simile, synecdoche and metonymy. According to the author, the figures in the latter group, the (M)-Type ones, are:

[...] semantic interpretations, interpretations determined by the semantic structure of the language; whereas (I)type figures are postsemantic, that is, uses the semantic interpretation of sentences, namely, propositions, to yield further propositions. (STERN, 2000, p. 237)

This view on hyperbole seems to undermine its theoretical status, giving it a somewhat secondary role in the meaning production process; or at least, it moves hyperboles and the other (I)-type figures away from the scope of linguistic inquiries. The pragmatic, rather than semantic, nature of hyperbole will be discussed presently in this paper; at the moment it suffices to say that placing the locus of hyperbole outside the realm of language seems to hinder its potential role as an object worth investigating by linguists, particularly those concerned with the cognitive dimension of meaning.

Engaged in an almost passionate - not to say, ironically, hyperbolic - defence of hyperbole against this apparent neglect, Webb (1993) claims that

(...) it is not accurate or fair to conclude that hyperbole is a secondary and derivative feat of the linguistic imagination. In fact, it could be argued that hyperbole constitutes the ultimate shape of all the tropes. The desire to magnify, 
${ }^{13}$ Available at: <http:// www.merriam-webster. com / d ictionary / literal>. Access: Sept. 2014. We have used here dictionary definitions, and not more academic or theoretic a 1 references, as the former somehow reflect the commonsensical view underlying what is meant here by "traditional view". enlarge and intensify is the basic drive of all tropical formations. Hyperbole is thus the primary trope, the Urtrope, not an aspect of but, on the contrary, the root of all rhetoric. It is the master trope. The one mad movement that all the other tropes imitate, shape and even minimize in their own particular ways. (WEBB, 1993, p. 16)

We do not necessarily share Webb's contention that hyperbole would be the "primary trope" or the "Ur-trope", as the metaphor of "race" or "contest" does not seem to be appropriate when the elements in comparison are theoretical constructs of vast complexity. To argue that hyperbole is more important or fundamental than metaphor would, in our view, distort the purpose of the present discussion, which is to understand both the cognitive and pragmatic roles of this particular way of expressing one's evaluation of the force or intensity of a state of affairs and some of the possible cognitivelinguistic realizations of this expression, including metaphor. We do align with Claridge's (2011, p. 19) less extreme claim, however, that "non-literal language is ubiquitous in everyday life, and while hyperbole is a major part of this, it has so far remained relatively unexplored". The discussion presented in the following section, thus, aims at briefly exploring the pragmatic and cognitive aspects of hyperbole.

\section{The pragmatic and/or functional role of hyperboles}

According to Cano Mora (2009), hy perbole can be defined as "a form of extremity, an exaggeration that either magnifies or minimizes some real state of affairs". It is often considered, in traditional semantic and rhetoric studies, a figure of speech, and, as such, it is used in a figurative or nonliteral sense. The on-line Merriam-Webster dictionary gives three definitions to literal: "involving the ordinary or usual meaning of a word; the meaning of each individual word; completely true and accurate: not exaggerated"13.

Hyperbole, therefore, has its value defined in terms of its opposition to what is literal, i.e., what is "true and accurate". This view is expressed in the diagram proposed by Claridge (2011): 


\begin{tabular}{|l|l|}
\hline \multicolumn{1}{|c|}{ Literal Expression } & \multicolumn{1}{|c|}{ Hyperbolic expression } \\
\hline $\begin{array}{l}\text { Agrees with the extralinguis- } \\
\text { tic facts in the given context } \\
\begin{array}{l}\text { Contains semantic attri- } \\
\text { bute expressing " } \mathrm{X} \text { " }\end{array}\end{array}$ & $\begin{array}{l}\text { Exceeds the (credible) limits } \\
\text { of fact in the given context } \\
\text { Contains attribute "more of } \\
\text { "X", i.e, "more of the same" }\end{array}$ \\
\hline
\end{tabular}

Gradability scale: (CLARIDGE, 2011, p. 5)

Hyperbole, however, as it was mentioned in the preceding section, has been distinguished from other tropes like metaphor and metonymy on the account of its essentially pragmatic nature. That hyperbole can be seen as a type of "illocutionary act", as it is argued by Stern (2000), is evidenced by some verbs which are used to refer to what hyperboles seem to do in real communication. Thus, to refer to hyperbolic expressions, it may be said that they a) exaggerate; b) amplify; c) intensify; d) magnify; e) overstate; f) inflate; etc. an utterance or an intensifiable element in the utterance. In other words, they seem to represent illocutionary acts themselves.

The same pragmatic explicitness does not necessarily apply in the case of metaphor or metonymy, for example. Apart from the poetic function (in Jakobson's term) a metaphor may play in discourse, the illocutionary act it performs is not so clear: the action of "metaphorizing" does not imply a predictable communicative act in itself. The epistemic (THIBODEAU; BORODITSKY, 2011) and/or argumentative functions of metaphor (OSWALD; RIHS, 2013) and its cognitive force are, today, considered irrefutable among most metaphor scholars, particularly after the present consensual rejection of the traditional view of metaphor, which approaches this figure merely as a language ornament, with no relevant effect on neither cognition nor meaning production. This overall function of metaphor, however, is not automatically translated into a clear illocutionary act, like the one which is characteristic of hyperboles, expressed by the verbs mentioned above (exaggerate, amplify, intensify, overstate, etc.). It might even 
be reasonable to suggest that metaphoric language would be a type of linguistic/semantic realization, with some undeniable specific cognitive effect, of illocutionary acts of varied nature: intensifying being one of them.

The functional dimension of hyperbole, on the other hand, as already stated above, is far more distinct and clearer, and, for this reason, it may be approached from the perspective of a systemic-functionally oriented framework, that of the Appraisal System, defined and theoretically developed by Martin and White (2005). The Appraisal System emerges from one of the macro functions of language proposed by Halliday, namely the interpersonal function, which concerns, according to Martin and White (2005, p. 1), "the subjective presence of writers/speakers in texts as they adopt stances towards both the material they present and those with whom they communicate".

Intensification, within the Appraisal System, would be a defining characteristic of the category of "Graduation", i.e., "how speakers/writers increase and decrease the force of their assertions and how they sharpen or blur the semantic categorizations with which they operate" (MARTIN; WHITE, 2005 , p. 2). Graduation, therefore, has to do with "adjusting the degree of an evaluation - how strong or weak the feeling is". (p. 37). It is our contention that hyperbole would belong to the graduation category of the Appraisal System, as it clearly indicates "the subjective presence of writers/speakers in texts as they adopt stances towards the material they present", and, semantically, would be located in an extreme point of a gradability scale (up-scaling).

Martin and White (2005) describe the different resources, from the lexico-grammatical system, which instantiate, linguistically, graduation. Most of these are pre- intensifying adverbs, which pre-modify adjectives (e.g., a bit tired; somewhat tired; very tired; extremely tired; overwhelmingly tired) and other adverbs (slightly abruptly; fairly abruptly; quite abruptly; very abruptly) and modify verbal groups (this upset me slightly, this upset me somewhat, this upset me greatly).

More importantly, considering the aim of the present paper, is a particular type of intensifier, described by Martin and White, namely the maximizers, which consist of "locutions which construe the up-scaling as being at the highest possible 
intensity, [...]this value often operates hyperbolically to convey strong writer/speaker investment in the proposition" (p. 142). The examples of this category given by the authors are: utterly miserable; totally miserable; thoroughly miserable; absolutely miserable; completely miserable. What interests us, however, are the maximizers which are classified as "figurative" (crystal clear, came out like a jack in the box, prices sky-rocketed [p.147-148]). The authors claim that collocations like these are so conventionalized and fixed, that the intensifying element (crystal, jack in the box, sky rocketed) no longer carries its full semantic load. Thus, according to them,

there is nothing semantically untoward about the fact, for example, that ice cold Coke is, in fact, virtually never ice cold. Similarly to characterize someone as deliriously happy is not to characterize them as delirious (a negative judgment of capacity), and is only subtly different from characterizing them as extremely happy. (MARTIN; WHITE, 2005, p. 143)

The view that conventionalized metaphors - often referred to as "dead metaphors" (MÜLLER, 2010) - are, from a pragmatic perspective, little ("subtly") or no different from their grammatical counterparts in the graduation lexicogrammatical system, the degree adverbs, is shared by other pragmaticians, such as Sperber and Wilson (2012). Theses authors claim that the expressions "Joan is incredibly kind" and "Joan is a Saint", whether they are classified as hyperbole or metaphor, respectively, would be interpreted, in the same way, both referring to "outstanding kindness" (p. 110).

Although we agree with the view that hyperbole plays a fundamentally pragmatic or functional role in meaning production, and that this role is interpersonal as it relates to the expression of subjectivity or evaluation of the intensity of a particular proposition, it is our contention that the instantiation of this "perceived outstanding intensity" in the form of a metaphor, even a highly entrenched or conventionalized one, produces a particular cognitive-discursive effect which is significantly different from that of a grammatical realization, like a degree adverb, for example. It is this cognitive specificity that justifies the distinction between metaphoric hyperbole, the concept which is the focus of the present paper, and the other grammatical hyperboles, mostly realized by degree adverbs. 


\section{The cognitive-discursive dimension of metaphoric hyperboles}

Two very basic cognitive structures - in fact, pre-conceptual structures, (HAMPE, 2005) - underlying hyperbolic language are those of size and scale.

With regard to the first one, Claridge points (2011) out that

hyperboles are features of everyday language. It maybe wired in the cognitive structuring of our experience. The concept of size, to which exaggeration must be primarily connected, is a very basic one. (CLARIDGE, 2011, p.7)

As to the concept of scale, it might be suggested that it is directly related to an image schema ${ }^{14}$ of the same name, i.e., scale, proposed by Johnson (1987). This encompasses other image schemas such as force and, according to Mandler (2014, p. 18), path: "[...] path directionality is most likely the initial basis of a scale schema". The basic conceptual structure of hyperbolic meaning, therefore, involves the conceptualization of sensorymotor experiences, linguistically reified. It might be implied, therefore, that all hyperboles, despite their dependence on contextual factors - thus their pragmatic dimension - have a clear cognitive basis.

Within the perspective of Cognitive Linguistics, metaphoric hyperboles, besides sharing this conceptual foundation with hyperboles of different forms (CLARIDGE, 2011) would also evoke another level of cognition beyond that of image schemas, even when they are highly conventionalized - or even "dead".

It might be reasonable to suppose that this further level of cognition lies in the very semantic nature of the source domain of the metaphor used in the hyperbolic expression. We propose that the point of the scale which is emphasized corresponds to

${ }^{14}$ According to Johnson (2005, p. 18-19), image schemas are "the recurring patterns of our sensory-motor experience by means of which we make sense of that experience and reason about it, and that can also be recruited to structure abstract concepts and to carry out inferences about abstract domains of thought". the most prototypical member of a semantic domain, which exhibits the aspects of the proposition which are highlighted.

In examples (16) and (17), used by Sperber and Wilson (2012) and Martin and White, 1995, respectively,

(16) John is a saint and

(17) The Coke is Ice-cold

saint is the prototype of a kind man; so kind that normal human beings could not normally be saints even if they wanted to: they 
are beyond possible and real kindness- thus the metaphoricity of the term in this context. By the same token, ice could be considered, commonsensically, the prototypical member of a domain of cold things. Literal icy-coke would be more like icecream than a soft drink: it would probably be undrinkable.

Some of the examples of metaphoric hyperboles presented in the introduction can illustrate what is meant by the role of prototipicity in metaphoric hyperboles:

(1) You are eating like pigs.

(3) He ran faster than the speed of lightning.

(7) His anger was so uncontrollable; it grew like the eruption of mountain Vesuvius.

(10) When her boyfriend broke off their engagement, she cried a river.

The choice of the metaphoric vehicle in these and in many hyperboles seems to be motivated by the prototipicity of the vehicle term. Thus, pig is a possible prototype of an animal that eats a lot; lightning, a possible prototype of a very fast (but visible) phenomenon; the eruption of the Vesuvius, a possible prototype of an uncontrollable eruption (and the Vesuvius, probably the most famous of all volcanoes), which stands for uncontrollable anger, as an effect of a mapping from a primary metaphor (ANGER IS HOT FLUID IN A CONTAINER) and river, large quantity of water.

The latter hyperbolic metaphor, cry a river, will be the focus of the brief analysis presented in the next section, which aims at illustrating the issues discussed so far and the view on hyperbole, particularly metaphoric hyperboles, which has been defended in this paper and which can be summarized as follows:

Metaphoric hyperboles, like all hyperboles, are motivated pragmatically, performing the function of intensifying a particular proposition. There are typical categories from the lexico-grammatical system used to realize this function; mostly, degree adverbs and figurative expressions. All hyperboles are conceptually structured by image schemas, such as scale and force. Metaphoric hyperboles also seem to be cognitively motivated by the use of a prototypical member of a domain referring to the particular quality or property which is to be 
amplified/intensified. This member (saint, volcano, lightning, ice, etc.) is prototypical with reference to the aspect that is the target of intensification. In this respect, the notion of "prototype" evoked here is not exactly the same as that proposed by Rosch (1978, 1983), since it does not refer to categories in general, but to a category defined on the basis of particular scales of gradability, as it is the case of hyperbole.

\section{The analysis: cry me a river}

Analyzing hyperbole in authentic electronic corpora is not a simple methodological procedure. According to Claridge (2011):

The phenomenon of hyperbole is not one that lends itself easily to a classical corpus linguistic approach, as automatic searching requires a list of search terms. With this approach one tends only to find what one already knows or suspects to be the case anyway. (CLARIDGE, 2011, p. 23).

Taking this limitation into account, a search in platform Google was conducted, using the search expression "cry a river", one of the metaphoric hyperboles included in the examples presented earlier in this paper. The aim was to investigate both the main collocates of the expression, as well as the most typical genres in which it occurs.

The search result indicated 299.000 entries. A significant part of these entries refers to three lyrics of the songs, with the same title: Cry me a river. The first song was written in 1953 by Arthur Hamilton, the second, in 2002, by Justin Timberlake and the third, in 2008, by Amy Grant:

(18)

Now you say you're lonely

You cried the long night through

Well you can cry me a river

Cry me a river

I cried a river over you

Our bridges were burned

And now it's your turn

To cry, cry me a river

Cry me a river, girl 
(20)

Cry a river

Flow the sea

Cry a river

Over me

When tender

winds blow

Sit on the shores

of love

And just let it go

In all three verses, crying can be interpreted, metonymically, as a result of a "broken heart". This explains the collocates "over me; over you" (the agent of the broken heart; the target of crying). The more heartbroken someone is, the more tears they will shed: amplifying the volume of tears and projecting them onto the image of a river seems to be a cognitively powerful way of stressing the strength of one's sorrow.

In example (19), Our bridges were burned, and now it's your turn to cry, cry me a river, the use of "bridges", implying interaction between lovers, expands the "river" metaphor within the same semantic field, creating a metaphor niche a textual development of a situated metaphor (VEREZA, 2013a). In example (20), the metaphor is further poetically explored: Cry a river, Flood the sea, [...] Sit on the shores of love, and just let it go; flood the sea (with your tears), shores (of the river made of tears), creating a powerful "water-oriented" extended metaphor, typical of poetic language (LAKOFF; TURNER, 1989), with evident hyperbolic effects.

Unlike its use in the examples above, "cry me a river" may also be employed to express lack of sympathy for someone's situation. In other words, to say that someone has cried a river over something seems to imply a certain criticism pointing to the fact that someone has cried too much without a justifiable reason, as in (21):

(21) It is rather shaming to be quite so wet over nothing in particular, but at least Fielding does it too. He cries gallons

${ }^{15}$ "Michele Hanson, "I cry over anything lately", Available at: $<<$ guardian.co.uk $>>, 4$ Mar. Access: Mar. 2015. over slow-motion bits at the ends of films, He can cry you a river over that one, and over a darling little clump of daffodils growing by the traffic island. ${ }^{15}$ 
The exaggeration here seems to imply, thus, both graduation (exaggeration) and judgement, following Martin and White's (2005) appraisal system categories.

From a more cognitive perspective, regarding a possible scale of intensity, one may simply cry, cry a lot, cry a river (a more conventional hyperbole), cry a sea, or even cry an ocean (less conventional hyperboles - mostly present, in the general corpus, in poems). Within this scale, from a cognitive perspective, evoking the sensorimotor dimension of experience (LAKOFF; JOHNSON, 1999), an ocean might probably be considered the potential prototype of "a large quantity of liquid" and, in the metaphoric hyperbole, it is used to refer to and highlight a large quantity of tears (liquid). Therefore, the prototype is used metaphorically with hyperbolic effects.

However, people don't cry water: they cry tears. But referring cognitively to the "water" element, metonymically associated with tears (substance for the object), the association with large "geographical containers" or recipients of water (rivers and oceans), both limited by land, is metaphorically established. In using "river", in cry a river, instead of "ocean", the element of movement (the flowing of the water in a river), besides that of quantity, is evoked; after all, crying (weeping) involves shedding tears (the flowing of liquid from one's eyes). It might be reasonable to suppose, therefore, that, in the case of crying, river is a more appropriate metaphoric hyperbole than ocean, as it encompasses both quantity and movement of water, thus its greater conventionality.

This does not mean, however, that the greater the conventionality of a hyperbole, the greater its cognitive effect; in fact, the opposite seems to be the case. As the communicative effect of a hyperbole is the amplified expression of the speaker's evaluation or appraisal (MARTIN; WHITE, 2006) of the intensity or strength of a particular fact (in this case, crying), a highly conventional metaphoric hyperbole, like all "dead metaphors", may not sound (or "feel", from the point of view of the speaker him/herself) sufficiently expressive, not conveying the intended subjective strength or force.

As a consequence, the hyperbole, as in the case of "sleeping metaphors" (MÜLLER, 2008), may be "revived", through the use of ocean - amplifying quantity even further than river or waterfall - amplifying both movement and pressure of 
water. A corpus search reveals that the latter, crying a waterfall, is particularly explored in imagery, as in visual metaphors (FORCEVILLE, 2005), like the examples in figure 1 and figure 2 :

Figure 1 - Cry a waterfall $(1)^{16}$

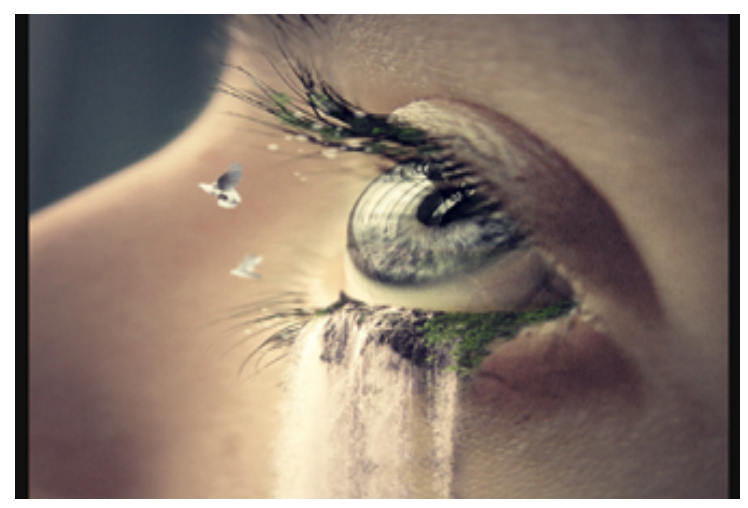

Figure 2 - Cry a waterfall (2) ${ }^{17}$

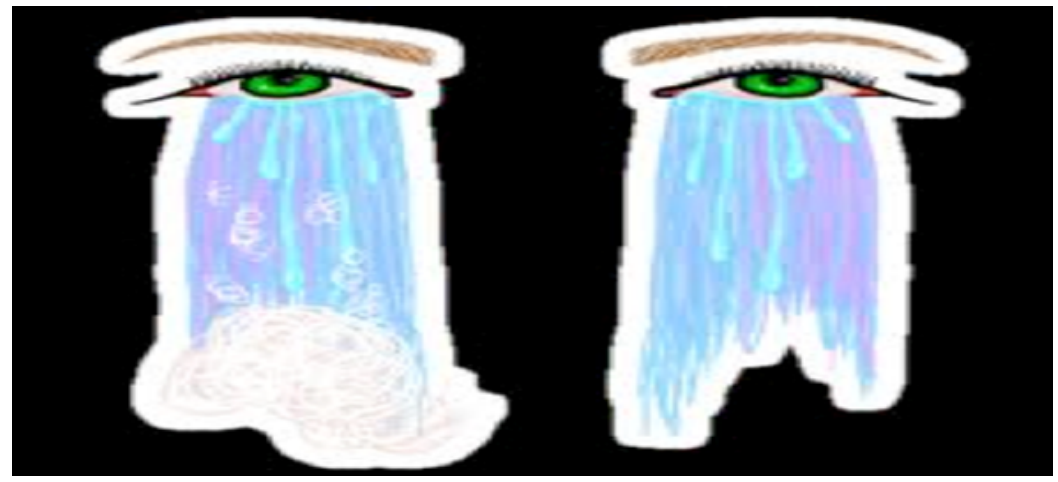

On the other hand, in cry an ocean, the intensity is cognitively established only through quantity, not movement.

${ }^{16}$ Available at: <http:// imblog.aufeminin. com/blog/D20111118/ $439354 \_873669146$ crymeariver_H183549 L.jpg>. Access Aug. 2013.

${ }_{17}$ Available at: <http:// www.redbubble.com/ people/theverse/ works / 7462388 . waterfall-tears-cryingeyes? $p=$ sticker $>$. Access: Aug. 2013. There is a certain type of movement in an ocean, mainly indicated by the succession of waves; but, besides not being so evident, there is no one-directed flowing. This means that the hyperbolic metaphor exploits the element of volume of liquid in the source domain ocean, a candidate for a prototype of this category, rather than in river or waterfall. Graphically, we can have the juxtaposition of the "literal volume" in literal crying and the metaphoric translation of this volume into "ocean of tears": 
Figure 3 - Cry an ocean ${ }^{18}$

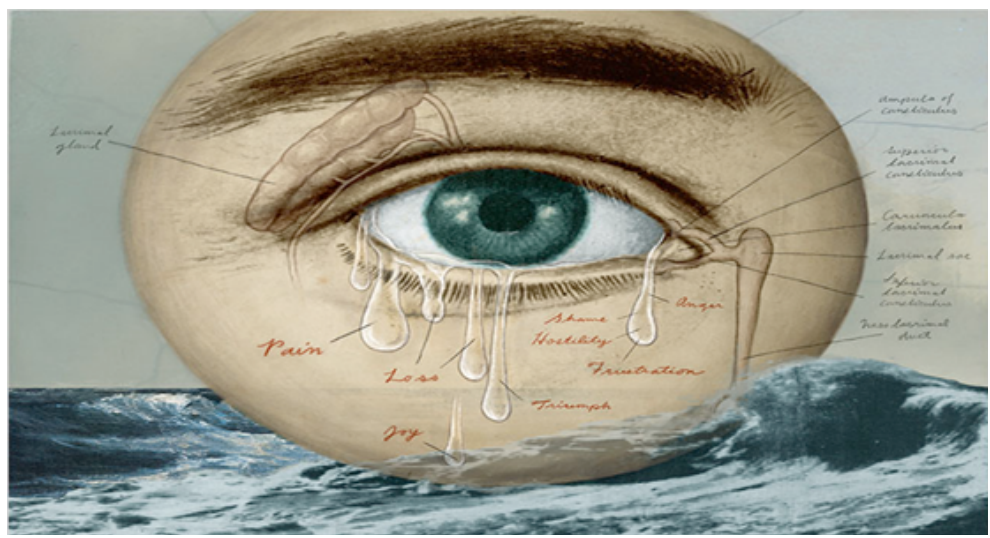

From a discursive perspective, then, the effect of amplification appears to be promoted through a combination of discursive and pragmatic factors, on the one hand, and more stable cognitive representations, such as frames and prototypes, on the other. This means that the dichotomy proposed by Stern (2000) between semantic and pragmatic figures does not seem to apply, at least in the phenomenon discussed in this paper, if the cognitive dimension of semantics is considered.

\section{Final Considerations}

Hy perboles are not simply a matter of exaggeration, if by exaggeration one means, violating, somehow, truth conditions. The use of hy perboles might be simply a form of expressing the true intensity of one's evaluation of the strength of a particular state of affairs, or its impact upon one's subjectivity. It is often, then, a matter of "feeling like $x$ ", or "with the intensity of $x$ ", and this feeling might be truly correspondent to that the speaker is experiencing.

Hyperboles expressed linguistically through metaphors seem to create a cognitive frame, which, at least potentially, enable the hearer to grasp the intensity of his/her interlocutor's response to a particular object or situation. From a cognitive

18 Available at: <http://1.bp.blogspot. com/_sy4MFQ5319g/ $\mathrm{S} 6 \mathrm{~d}$ V 8 r B x D w I/ A A A A A A A A oc/ urCEnW3rrhY/s400/ chorar.jpg>. Access: May 2014. perspective, hyperbolic metaphors presuppose a combination of image schemas, such as scale and force, and prototypes, which convey, in a language community's repertoire, the highest degree of intensity of what is under subjective evaluation. Thus, a river would be a prototype of a "large 
quantity of flowing water"; a "pig" would be a candidate for a prototype of an animal that eats large quantities of food; "lightning", a very fast, almost instantaneous, phenomenon; the "Vesuvius", or simply, a volcano, a prototype of very intense hot fluid discharge, which intensifies the ANGER IS A HOT FLUID primary metaphor, and so on.

In this sense, and to answer, tentatively, the questions presented in the introduction of this paper, it might be reasonable to suppose that many, not to say most, metaphors, like the classic "Juliet is the sun", or a conventional one, like "Peter is an ox", are, in a way, hyperbolic, since the vehicle term could be seen as the prototype of the feature which is highlighted: the brightness of the sun and the strength of an ox, respectively. This is one of the reasons the concept "metaphoric hyperbole" seems to be theoretically more appropriate than "hyperbolic metaphor". Hyperboles, or the amplification of force or intensity, can be realized or instantiated by several linguistic forms (adverbs of degree, prosodic elements and metaphors), but most metaphors, somehow, seem to imply a hyperbolic mapping of an element (a prototy pe candidate) from the target domain. In this paper, this has been approached more as a hypothesis than a definite claim, and, as such, it has been explored in the brief analysis of the conventional metaphoric hyperbole "cry me a river". This analysis has indicated the need and the potentiality of the hypothesis for further research, combining insights from the areas of Cognitive Linguistics (with focus on image schemas, prototype theory and conceptual metaphor), Appraisal Theory (with focus on the subsystem of graduation) and Pragmatics (with focus on amplification as a possible type of expressive speech act). Investigating hyperboles within this perspective, thus, can shed light on the multidimensional nature of language use and on the interweaving of more stable (such as prototype and conceptual metaphors) with more episodic (illocutionary force and online frames (VEREZA, 2013b) levels of meaning production.

\section{REFERENCES}

BARCELONA, Antonio. Metaphor and metonymy at the crossroads: a cognitive perspective. Berlin: Mouton de Gruyter, 2003. 
CANO MORA, L. Do we ever make a molehill out of a mountain? Antithetical extremes in the expression of hyperbole. In: Revista Eletrônica de Linguística Aplicada, v. 7, pp.105-117, 2008.

CLARIDGE, Claudia. Hyperbole in English: a corpus-based study of exaggeration. Cambridge: Cambridge University Press, 2010. DIRVEN, René.; PÖRINGS, Ralf. (Eds.). Metaphor and metonymy in comparison and contrast. Berlin: Mouton de Gruyter, 2003.

FORCEVILLE, C. Metaphor in pictures and multimodal representations. In: GIBBS, R. (Ed.), The Cambridge Handbook of Metaphor and Thought. Cambridge: Cambridge University Press. pp. 462-482, 2008.

GIBEAN, Claire. J. Hyperbole Examples: Extensive exaggerations to make a point. Bloomington: Author House, 2010.

HAMPE, B. Image Schemas in Cognitive Linguistics: Introduction. In HAMPE, B. (Ed.). From Perception to Meaning: image schemas in cognitive linguistics. Berlin: Mouton de Gruyter, 2005.

JOHNSON, M. The philosophical significance of image schemas. In: HAMPE, B. From Perception to Meaning: image schemas in cognitive linguistics. Berlin: Mouton de Gruyter, pp. 15-33, 2005.

The Body in the Mind: the bodily basis of meaning, imagination, and reason. Chicago: University of Chicago, 1987.

KLEIN, Henny. Adverbs of Degree in Dutch and Related Languages. Amsterdam: John Benjamins, 1998.

LAKOFF. G.; JOHNSON. M. Metaphors we Live by. Chicago: Chicago University Press, 1980.

Philosophy in the Flesh: the embodied mind \& its challenge to western thought. New York: Basic Books, 1999.

LAKOFF, George.; TURNER, Mark. More than Cool Reason: a field guide to poetic metaphor. Chicago: University of Chicago Press, 1989.

MANDLER J. M.; CÁNOVAS C. P. On defining image schemas. In: Language and Cognition, Vol. 6 -04, pp. 510-532, 2014.

MARTIN, Jim.; WHITE, Peter. Language of Evaluation: appraisal in English. Londres: Palgrave Macmillan, 2010. 
MIRANDA, N. S. Construções gramaticais e metáfora. In: Gragoatá, n. 26, pp. 61-80, 2009.

MÜLLER, Cornelia. Metaphors Dead and Alive, Sleeping and Waking: a dynamic view. Chicago: University of Chicago Press, 2008. OSWALD, A.; RIHS, S. Metaphor as Argument: rhetorical and epistemic advantages of extended metaphors. In: Argumentation, v. 28, pp.133-159, 2013.

ROSCH, E. Principles of Categorization. In: Rosch, E. \& Lloyd, B.B. (Ed.), Cognition and Categorization. Hillsdale: Lawrence Erlbaum, pp. 27-48, 1978.

. Prototype Classification and Logical Classification: the two systems. In: Scholnick, E. K. (Ed.), New Trends in Conceptual Representation: Challenges to Piaget's Theory? Hillsdale: Lawrence Erlbaum Associates. pp. 73-86, 1983.

SPERBER, Dan.; WILSON Deirdre. Meaning and Relevance. Cambrige: Cambridge University Press, 2012.

STERN, Josef. Metaphor in Context. Cambridge, Ma: The MIT Press. 2000.

THIBODEAU, P. H; BORODITSKY, L. Metaphors We Think With: the role of metaphor in reasoning. In: PLOS ONE 6(2), pp.16782-16793, 2011.

VEREZA, S. Discourse, cognition and figurative language: Exploring metaphors in political editorials. In: Silva. A. S., et al (Eds). In: Comunicação Política e Económica: Dimensões Cognitivas e Discursivas. Braga: Publicações da Faculdade de Filosofia Universidade Católica Portuguesa pp. 383-394. 2013a. . Entrelaçando frames: a construção do sentido metafórico na linguagem em uso. In: Cadernos de Estudos Linguísticos, vol. 55.1, pp. 109-124, 2013 b.

WEBB, Stephen. H. Blessed Excess: religion and the hyperbolic imagination. New York: State University of New York Press, 1993. 


\section{Resumo}

Cry me a river: hipérbole metafórica na interface entre discurso e cognição

Este trabalho tem por objetivo analisar a metáfora como uma frequente manifestação semântica da "linguagem do excesso" (WEBB, 1993), ou seja, a hipérbole. Duas hipóteses são exploradas: em primeiro lugar, a partir de uma perspectiva discursiva, hipérboles transcenderiam um repertório linguístico disponível para a expressão da intensidade e da gradação e, como consequência, da subjetividade. Nesse sentido, as metáforas, tanto convencionais como novas, realizam, linguisticamente, essa intensidade, com efeitos discursivos e cognitivos, ao recrutarem elementos do domínio fonte que desempenham esse duplo papel. A segunda hipótese que norteia a pesquisa se refere à natureza conceitual do termo veículo, ou seja, a hipérbole metafórica. A proposta é de que, dentro de uma escala conceitual de intensidade, o elemento selecionado é o protótipo dessa categoria, que é usado metaforicamente, com efeitos hiperbólicos. O referencial teórico se apoia nos seguintes conceitos: hipérbole, tal como definido em Claridge (2011), gradação (MARTIN; WHITE, 2005), metáfora conceptual (LAKOFF; JOHNSON,1980) e protótipo (ROSCH, 1979, 1983). Uma breve análise, com exemplos retirados de um corpus geral, da expressão hiperbólica cry me a river, convencional na língua inglesa, ilustrará a discussão proposta.

Palavras-chave: hipérbole; metáfora; cognição. 